\title{
Nation-Building through Constitutionalism
}

\author{
Tengku Ahmad Hazri*
}

States face the challenge of balancing their roles as both strong and limited-i.e. strong because the people depend on them for their shared identity, purpose and direction, yet limited in order to ensure the rights and liberties of those people are safeguarded.

Nation-building projects have the tendency to compromise on human rights and fundamental liberties, not least because the very idea of a "shared identity" often involves the marginalisation of other histories - or "historical amnesia" as it has been called - as the emphasis is placed on shared history.

But, the limited nature of the nation-state often means there is not much by way of history to identify with. Hence, communities are often inclined to identify themselves with civilisations that transcend the contours of their own state, thereby connecting themselves with the history of others. This is especially true because of an intrinsic sense of solidarity between people belonging to the same cultural tradition.

This can, however, lead to a backlash if such practices spill over into diplomatic issues. If they are interpreted by one state as disrespectful of their or another's sovereignty, it can lead to conflict. This in turn further reinforces the need for a strong state capable of asserting its sovereignty and reaffirming its commitment to protect the rights and welfare of its citizens, irrespective of their ethnic, religious or cultural backgrounds - in other words, to reaffirm its commitment to human rights.

The effective balance and reconciliation between these seemingly contradictory demands - for the state to be concurrently strong-expansionist and minimal-limited, to promote nation-building on the one hand and yet safeguard individual rights on the other-is a critical factor in a community's stability. Without a strong state to promote a sense of common identity and unity, a community disintegrates into sectarian enclaves, all at odds with each other. Without a limited state, in which the state refrains from interfering in the private lives of citizens, the state will also lose legitimacy.

Not infrequently, the dynamics in this conflict find expression in the constitutional text of the nation-state. A constitution typically has two components, namely the instrumental and the symbolic. The instrumental features are those that set out the institutional framework and infrastructure of government, including 
the powers and duties of offices and the procedure for election, appointment and removal of offices. The symbolic features are those that do not seem to serve direct utility or function, but rather endow the constitution, the state and the nation with their distinctive identity or philosophy. These include provisions on official religion, national language, traditional institutions such as the monarchy (where its role is strictly ceremonial) and even a national ideology. While the instrumental features of the constitution are needed to ensure the smooth operation of the state and its organs, the symbolic aspects confer legitimacy on the nation-state by connecting it with the history and moral order of the people. These aspects connect to history by the retention of traditional values and institutions, and to moral order by inscribing into the text what is already normatively held as the ideals of the people.

The past few decades have witnessed an intensification in conflicts worldwide, resulting in the construction and reconstruction of new states. As states move towards reinventing themselves, they adopt new constitutions to reflect their commitment to change. Thereby they hope to engender stability and security. The Islamic world is especially vulnerable to this trend, particularly in the Middle East. The Arab world once struggled to accommodate its own realities, only to have those dreams shattered after the failed promises of the Arab Spring, which only served to produce mayhem and IS, which self-consciously seeks to obliterate the boundaries imposed by the "Sykes-Picot conspiracy".

In post-conflict reconstruction efforts, nation-building is just as important as state-building. Yet while state-building can be worked out, nation-building is much more difficult. Indeed, nation-building is conceived of as "an art, not a science," requiring a vast knowledge of local circumstances, substantial native input and the creation of largely symbolic, non-tangible things (like national languages). These are crucial, not only to give legitimacy to the state, but also to provide the people with a sense of identity, direction and purpose. This effort, however, is not small and therefore requires vast resources, especially in settings where civil society is weak, as might be the case in post-conflict zones. This typically requires a strong and active role by the state. The state's role is also important in order to prevent disenfranchised groups from lapsing into extremism. In this regard, Rachid Ghannouchi has attributed the relative success of Tunisia (certainly compared to other post-Arab Spring states, like Egypt and Libya) to the fact that Tunisia was not impeded by sectarian groups given its relatively homogenous society.

At the same time, however, the state should also respect the freedoms and liberties of the people. Failure to secure this basic component will mar its image on the international stage, and often pave the way for intervention by others.

Given these two-fold commitments, states are often pressed with the 
paradoxical need to be both expansionist (to forge unity, solidarity and give a sense of direction) and minimalist (to respect freedoms and rights) at the same time.

\section{Notes}

* Tengku Ahmad Hazri is Research Fellow at IAIS Malaysia. He may be reached at ahmhazri@iais.org.my. 